\title{
Editorial
}

As normas imperativas de direito internacional (jus cogens) tiveram sua consagração normativa nas Convenções de Viena sobre Direito dos Tratados de 1969 e 1986. Tal previsão convencional estimulou o estudo do tema pela doutrina, que a cada dia vem se dedicando mais ao assunto, com ampla produção. Sabe-se, entretanto, que o desenvolvimento pleno de um instituto tão polêmico exige uma aplicação prática constante e consciente, de modo a se incorporar no cotidiano das relações internacionais.

É nesse campo que o jus cogens encontra-se fragilizado, tendo em vista a reticência dos tribunais internacionais em utilizá-lo em seus julgamentos, dando-Ihe vida e estimulando seu aperfeiçoamento. A Corte Internacional de Justiça - CIJ, instituição que definitivamente poderia dinamizálo, resiste até mesmo em utilizar a expressão jus cogens, apesar das inúmeras oportunidades que teve para fazê-lo. Decisões falam, por exemplo, em "convicção humanitária" (Caso Sudoeste Africano), "obrigações erga omnes" (Caso Barcelona Traction) "caráter imperativo das obrigações" (Caso do pessoal diplomático e consular dos EUA em Teerã), "princípios intransponíveis" (Parecer sobre Armas Nucleares) ou fazem citações indiretas que tratam de jus cogens (Caso atividades militares e paramilitares na e contra a Nicarágua).

Em alguns casos a ClJ definitivamente perdeu o momento, tal como ocorreu no Caso Arrest Warrant (República Democrática do Congo contra Bélgica) em que se poderia ter dado novos contornos a institutos como imunidade diplomática, jurisdição universal, direito internacional costumeiro e mesmo jus cogens, ou mais recentemente na decisão de 3 de fevereiro de 2006, no caso das Atividades Armadas sobre o Território do Congo (Congo v. Ruanda), quando a Corte praticamente rejeitou o caráter imperativo das normas contra o genocídio, ao afastar a tese de que as disposições materiais da Convenção sobre Genocídio, amplamente consideradas jus cogens, constituem o objeto e a finalidade da Convenção, o que, conseqüentemente, não se lhes permitiria ser objeto de reserva pelos Estados..

Revista Brasileira de Direito Internacional, Curitiba, v.5, n.5, jan./jun.2007 
Nesse foro, o uso mais contundente do jus cogens limita-se a algumas intervenções das partes e a certos votos individuais de juízes menos retrógrados. Na mesma linha, a Corte Européia de Direitos Humanos e outros tribunais internacionais têm se mostrado resistente em relação às normas imperativas.

Em sentido contrário, entretanto, encontra-se a atuação do Tribunal Penal Internacional para a ex-lugoslávia, sobretudo pela atuação de Antonio Cassese, e, principalmente, da Corte Interamericana de Direitos Humanos, impulsionada pelo espírito crítico e progressista de seu então presidente, Antonio Augusto Cançado Trindade.

Jus cogens já havia aparecido em vários casos interamericanos como Villagrán Morales v.Guatemala; Las niñas Yean y Bosico v. República Dominicana, Yatama v. Nicarágua; Maritza Urrutia v. Guatemala e Blake v. Guatemala. Entretanto, a ampliação do conteúdo normativo do jus cogens deuse, efetivamente, pelas mãos de Cançado Trindade, no Parecer sobre a Condição Jurídica e os Direitos do Migrantes Indocumentados (Opinião Consultiva (OC) no. 18, de 2003), no qual afirma aos direitos de igualdade e não-discriminação o status de norma imperativa, e nas sentenças dos casos Almonacid e outros (de 27 de setembro de 2006, sobre as violações cometidas no regime de Pinochet, no Chile) e Goiburu e Outros (de 22 de setembro de 2006, sobre as atrocidades cometidas pelo regime de Stroessner, no Paraguai), ambas confirmando o direito de acesso à justiça no âmbito nacional e internacional como jus cogens.

O presente número da Revista Brasileira de Direito Internacional tem exatamente o objetivo de reunir estudos sobre essas novas orientações jurisprudenciais que envolvem as normas imperativas, sobretudo aqueles realizados pelos membros do Programa de Extensão "Núcleo de Estudos em Direito Internacional" da UFPR, além de autores convidados. Assim, os artigos tratam de temas como a proibição da pena de morte, a proteção das crianças, dos trabalhadores indocumentados e dos apátridas

É mais uma contribuição, ainda que singela, para o debate em torno do jus cogens, sempre com o objetivo de promovê-lo e desenvolvê-lo, de modo a 
consagrar os valores mais caros da sociedade internacional, com foco nos Direitos Humanos.

\section{O Editores:}

Professora Doutora Tatyana Scheila Friedrich - Coordenadora Docente do Núcleo de Estudos em Direito Internacional da Universidade Federal do Paraná e Editora Docente da Revista Brasileira de Direito Internacional

Cássio Eduardo Zen - Bolsista-extensionista do Núcleo de Estudos em Direito Internacional da Universidade Federal do Paraná e Editor Discente da Revista Brasileira de Direito Internacional 